\title{
In Vitro Propagation of the Erect Thornless 'Navaho' Blackberry
}

\author{
Gina E. Fernandez and John R. Clark ${ }^{2}$ \\ University of Arkansas Fruit Substation, Clarksville, AR 72803
}

Additional index words. Rubus spp., vegetative propagation

Erect blackberries (Rubus spp.) are often established through direct planting of root cuttings or from containerized plants grown from root cuttings (Caldwell, 1984). Shoot emergence from root cuttings of the erect thornless blackberry 'Navaho' has been poor; setting of rooted plants or closely spaced root cuttings was suggested to achieve adequate plot fill (Moore and Clark, 1989). The use of tissue-cultured plants would eliminate the need for root pieces and allow uniform spacing of plants in the field.

Successful in vitro propagation has been achieved with other blackberry cultivars (Broome and Zimmerman, 1978; Skirvin et al., 1981); however, difficulty has been reported in finding a suitable method for ' $\mathrm{Na}$ vaho' (J.N. Moore, personal communication). This study was conducted to develop an in vitro propagation regime for 'Navaho'.

Root cuttings from plants of 'Navaho' were dug from the field in early Fall 1989 and placed in cold storage (4C) for 2 to 4 months, until needed. Roots were cut into pieces 15 to $20 \mathrm{~cm}$ long, disinfested with $1.6 \% \mathrm{NaOCl}$ (30\% chlorine bleach), and placed in 0.5 liter canning jars with moistened paper towels (Anderson, 1980). The jars were loosely covered with aluminum foil lids and placed

Received for publication 3 Dec. 1990. Published with approval of the Director, Arkansas Agricultural Experiment Station. The cost of publishing this paper was defrayed in part by the payment of page charges. Under postal regulations, this paper therefore must be hereby marked advertisement solely to indicate this fact.

${ }^{1}$ Research Specialist. Present address: Dept. of Fruit and Vegetable Science, Cornell Univ., Ithaca, NY 14853

${ }^{2}$ Resident Director. in darkness at $25 \mathrm{C}$ for 10 to 14 days until etiolated shoots arose. Jars containing roots with such shoots were transferred to a $16-\mathrm{h}$ photoperiod $\left(33 \mu \mathrm{mol} \cdot \mathrm{s}^{-1} \cdot \mathrm{m}^{-2}\right)$ under coolwhite fluorescent lights for 3 to 4 days to induce chlorophyll development.

Aseptic cultures were initiated by removing green shoots from root pieces, disinfesting for 6 to $8 \mathrm{~min}$ in $0.5 \% \mathrm{NaOCl}(10 \%$ chlorine bleach) and $0.01 \%$ Tween 20 solution, and rinsing in sterile distilled water three times. Shoots were aseptically cut into 1- to 2-cm one-node segments. Four singlenode segments were cultured for 3 to 5 days per $100-\mathrm{mm}$ petri dish that contained $20 \mathrm{ml}$ of medium. The initial medium was one-half strength Murashige and Skoog (MS) (1962) with $30 \mathrm{~g}$ sucrose and $0.3 \mathrm{~g}$ acid-washed activated charcoal/liter (Sigma, St. Louis). All cultures were kept under the light conditions noted. Nodal segments (120) were then transferred to $120-\mathrm{ml}$ baby food jars (one segment per jar) for 3 weeks of proliferation. The jars contained $25 \mathrm{ml}$ of one of three media: full strength MS plus $0.3 \mathrm{~g}$ acidwashed activated charcoal/liter (A); full strength MS (B); and one-half strength MS (C). All three media were supplemented with $30.0 \mathrm{~g}$ sucrose/liter, $7.0 \mathrm{~g}$ agar/liter (Sigma) $8.9 \mu \mathrm{M} \mathrm{N}$-(phenylmethyl)1H-purine-6-amine (BA), $0.5 \mu \mathrm{M}$ 1H-indole-3-butyric acid (IBA), $0.29 \mu \mathrm{M}$ gibberellic acid (GA).

Nodal segments cultured on Medium A produced vigorous nonproliferating shoots with several long roots. Nodal segments cultured on $\mathrm{B}$ and $\mathrm{C}$ were very similar and formed three to five adventitious shoots but no roots. Clumps of proliferating shoots from B and $\mathrm{C}$ were divided and subcultured on the same respective media for continued proliferation, although microshoots on B developed slight chlorosis. Single microshoots, removed from proliferating clumps from B and C and transferred to A, grew vigorously with numerous roots without shoot proliferation. About $90 \%$ of all microshoots transferred to A produced roots within 2 weeks, with the only losses due to contamination of the vessel.

Plants that produced several long roots and four fully expanded leaves were transferred to nonsterile, transparent $270-\mathrm{ml}$ plastic cups filled with fine moistened vermiculite. An inverted clear plastic cup was placed on top of the first and held in place with parafilm. Plants were gradually acclimatized to ambient laboratory conditions by cutting successively larger holes in and finally removing the top cup. Rooted plants were planted in Promix BX (Premier Brands, New Rochelle, N.Y.) and placed in the mist bed for 1 week. Plants were then placed on a greenhouse bench for continued growth.

The length of time required for the various stages included 10 to 14 days for roots to sprout and grow etiolated shoots, 3 to 4 days of exposure to light for chlorophyll development, 3 to 5 days on the initial medium (one-half strength MS), 3 weeks in the proliferation medium, and, finally, 2 weeks on the rooting medium (A). Establishment in vermiculite in the transparent cups took $\approx 3$ weeks. The entire propagation procedure required $\approx 10$ to 11 weeks. The success rate of this procedure was $\approx 90 \%$, and the majority of the failures that occurred were due to contamination of the culture vessel.

\section{Literature Cited}

Anderson, W.O. 1980. Tissue culture propagation of red and black raspberries. Acta Hort. 112:1320

Broome, O.C. and R.H. Zimmerman. 1978. In vitro propagation of blackberry. HortScience 13:151-153.

Caldwell, J.D. 1984. Blackberry propagation. HortScience 19:193-195.

Moore, J.N. and J.R. Clark. 1989. 'Navaho' erect thornless blackberry. HortScience 24:863-864.

Skirvin, R.M., M.C. Chu, and E. Gomez. 1981. In vitro propagation of thornless trailing blackberries. HortScience 16:310-312. 